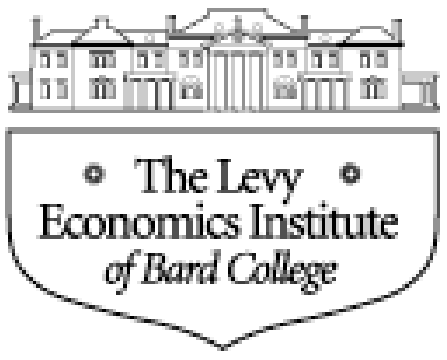

Working Paper No. 412

\title{
The Transmission Mechanism of Monetary Policy: A Critical Review
}

\author{
by \\ Greg Hannsgen, \\ The Levy Economics Institute of Bard College \\ hannsgen@levy.org
}

October 2004

The Levy Economics Institute Working Paper Collection presents research in progress by

Levy Institute scholars and conference participants. The purpose of the series is to disseminate ideas to and elicit comments from academics and professionals.

The Levy Economics Institute of Bard College, founded in 1986, is a nonprofit, nonpartisan, independently funded research organization devoted to public service. Through scholarship and economic research it generates viable, effective public policy responses to important economic problems that profoundly affect the quality of life in the United States and abroad.

\author{
The Levy Economics Institute \\ P.O. Box 5000 \\ Annandale-on-Hudson, NY 12504-5000 \\ http://www.levy.org
}

Copyright (C) The Levy Economics Institute 2004 All rights reserved. 


\section{INTRODUCTION}

Recently, many economists have credited the late-1990s economic boom in the United States for the easy money policies of the Federal Reserve. On the other hand, observers have noted that very low interest rates have had very little positive effect on the chronically weak Japanese economy. It would be useful to have some theory of how money affects the economy. Most analyses of the way in which monetary policy affects GDP and its components (the monetary transmission mechanism) assume that the central bank dictates the exact amount of money circulating at any given time. Post-Keynesian and other heterodox authors, in propounding the theory of endogenous money, argue instead that the central bank cannot control the money supply. Is there a theory of how money affects the economy when it is endogenous (Arestis and Sawyer 2003)?

Since endogeneity implies that the amount of money in the economy adjusts to demand, endogenous money theorists cannot base their theories on the notion that too much or too little money is in circulation. This amount is not subject to manipulation by policy. Instead, the effects of monetary policy must arise because policy affects interest rates. Since endogenous money theorists emphasize that money originates when credit is issued by banks, postKeynesian monetary thinkers emphasize the effects of interest rates on credit. Moreover, the ideas presented here involve the effects of money on real variables, such as GDP, rather than inflation. Most post-Keynesian economists believe money can affect prices and inflation, but they argue that these effects are indirect and of secondary importance to cost increases.

Numerous alternative means exist to explain the transmission mechanism, and many of them will be described in this paper. First, because investment has historically been one of the most volatile components of output, many theories concentrate on the effects of interest rates on fixed investment and inventories. Specifically, interest rates affect the price of money in the financial markets, and firms will not undertake an investment project if it yields a return less than this price. Second, cash flow is actually a much more important source of investment funds than borrowing; it will be shown that cash flow can either weaken the case for the centrality of interest rates or complement it. Third, and closely related to the second point, interest rates are an important cost for the firm; as such they affect prices and the distribution of income among "factors of production." Fourth, consumer borrowing can contribute greatly to the demand for goods and services, and borrowing may be at least somewhat sensitive to the interest rate. Fifth, 
interest rate levels can affect international flows of capital, which in turn has the potential to change exchange rates. Since exchange rates are extremely important variables in their own right, they should be taken into consideration in analyzing the transmission mechanism. Sixth, borrowed money can be used to purchase financial assets, not just capital goods. Hence changes in the cost of borrowing may affect the markets for bonds and stocks, which in turn affect real output.

The paper closes with a consideration of the term structure and risk premia of interest rates, which are dealt with in more detail elsewhere in this paper. This topic is very important for the monetary transmission mechanism because few of the effects of monetary policy listed above depend directly upon the short-term interest rates controlled by central banks. Rather, they depend on the rates available on commercial paper and bonds, mortgages, and so on. It is not always the case that the central bank can move these rates as it wishes. The paper will discuss mainly Keynes's ideas on this issue, because, as is often the case, Keynes identified the key issues at stake, and future work will build from his.

$* * *$

Before beginning with a taxonomy of interest rate effects, it is useful to consider the bottom line: do interest rate changes (somehow) influence the level of economic activity? Below is an "impulse response function" from a vector autoregression with three monthly variables: the federal funds rate, industrial production (a measure of economic output), and the consumer price index (in that order). The latter two variables are used in log form and 24 lags of all variables are included in each equation. ${ }^{1}$ The impulse response function shows how output and prices react to a random shock to the interest rate, in this case a shock of one standard deviation in magnitude. The paths are surrounded by vertical bars of two standard deviations in height. The graph shows a statistically significant fall in output and a rise in prices in response to the hypothetical interest rate shock. The effect on output is greatest at a time horizon of approximately 24 months. These findings have been partially replicated using data from the 10 economies that now form the euro area: a positive shock to the base interest rate leads to a temporary fall in output that peaks at three to six quarters after the shock (Mojon and Peersman 2003). This data indicate that monetary policy does have significant effects over a fairly long period of time. It remains to be seen how and why these effects happen. 
FIGURE 1

\section{Impulse Responses to one SE shock in the equation for FFR (1954-2002)}

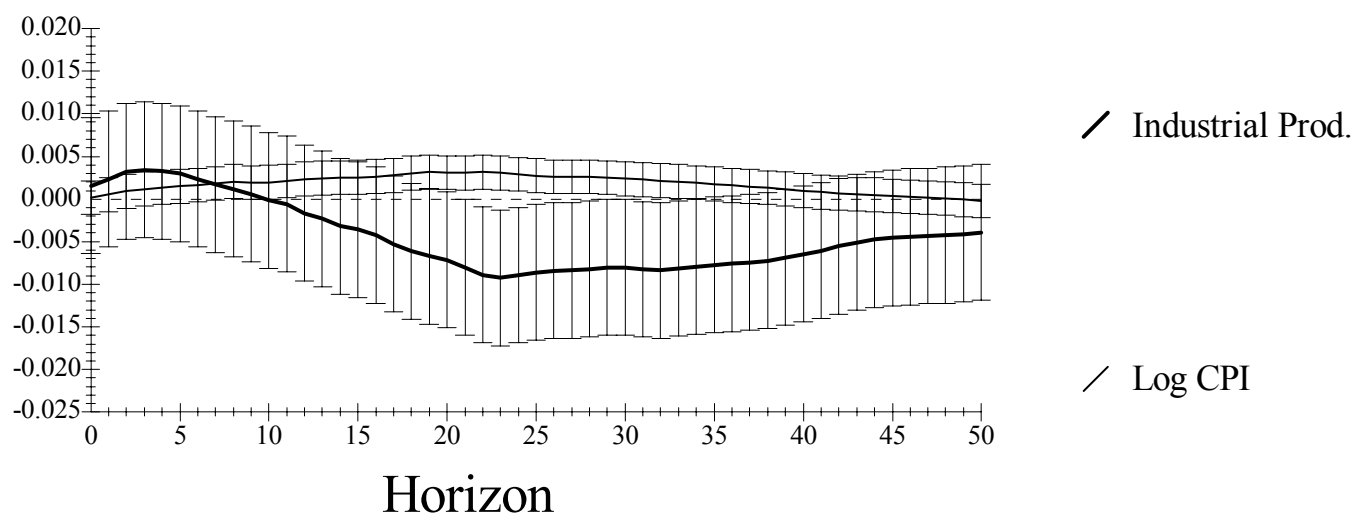

Source: Economagic. com and author's computations. Data: monthly, August 1954 to June 2002. Figure shows impulse response of the logs of industrial production and the consumer price index (CPI) to a one-standarddeviation shock in the federal funds rate (ffr). Regression equations included 24 lags of all variables. Identified using Cholesky scheme, with the variables ordered as follows: ffr, industrial production, CPI.

$* * *$

Basil Moore, one of the first and most effective proponents of the theory of endogenous money, sees the transmission mechanism as operating through the equalization of various rates of return (Keynes 1936; see also Rogers 1989). Indeed, this is the primary alternative theory of the monetary transmission mechanism. If the real rate of interest exceeds the rate of return on investment, businesses will increase their investments until the two returns are equal.

Alternatively, firms use the nominal interest rate to determine the net present value of potential investment projects. An increase in the expected stream of returns or a fall in the interest rate increases the net present value of investment projects. What is important here is the ex ante real rates of return (Moore 1988, p. 258). Firms can only estimate the rate of inflation; hence they do not know the ex post real rate of interest. Similarly, firms can only guess at the returns their investments might yield, as in Keynes's General Theory (1936, Ch. 12). The nominal interest rate is exogenously fixed, so it is the profit rate that must adjust to the interest rate, rather than vice-versa. Thus, by wielding its policymaking authority, the central bank can affect the ex ante real interest rate, and so, strongly influence investment. 
This view can be represented by an equation showing the net present value (NPV) of a particular project

$\mathrm{NPV}=-\mathrm{C}+\mathrm{Q}_{1} /(1+\mathrm{r})+\mathrm{Q}_{2} /(1+\mathrm{r})^{2}+\mathrm{Q}_{3} /(1+\mathrm{r})^{3}+\ldots .+\mathrm{Q}_{\mathrm{N}} /(1+\mathrm{r})^{\mathrm{N}}$

where $\mathrm{C}$ is the cost of the project (assumed to be incurred entirely in period 0), the $\mathrm{Q}_{\mathrm{i}}$ 's are the returns to the investment in each of the subsequent periods ( 1 through $\mathrm{N}$ ), and $\mathrm{r}$ is the discount rate (presumably the rate at which funds can be borrowed on the bond market). As the interest rate $\mathrm{r}$ rises, the net present value of each available project will fall. At any given time, a certain number of projects will have a positive NPV, and the firm will undertake those projects. In this view, the central bank can cause private investment to increase by lowering interest rates, which will cause more projects to have a positive NPV.

$* * *$

It cannot be emphasized enough that the $\mathrm{Q}_{\mathrm{i}}$ 's in the equation above are merely estimates of uncertain quantities. The $\mathrm{Q}_{\mathrm{i}}$ 's are profits, which depend not only on the physical productivity of a new plant or other investment, but also on the firm's ability to sell the product a number of years into the future. In fact, it was in his chapter on investment that Keynes emphasized most the importance of fundamental uncertainty (Keynes 1936, ch. 12). This notion contrasts with the neoclassical notion of uncertainty. In, for example, a neoclassical general equilibrium setting, all agents know that certain "states of the world" will obtain with certain probabilities. For example, the probability of rain tomorrow might be 50 percent. The agent can prepare for any eventuality by purchasing commodities that are contingent on certain states of affairs, for example, one umbrella in the event of rain.

The type of uncertainty contemplated in Keynes's theory was much different: "The game of roulette is not subject, in this sense, to uncertainty; nor is the prospect of a victory bond being drawn. Or, again, the expectation of life is only slightly uncertain. Even the weather is only moderately uncertain. The sense in which I am using the term is that in which the prospect of a European war is uncertain, or the price of copper and the rate of interest twenty years hence, or the obsolescence of a new invention, or the position of private wealth owners in the social system in 1970. About these matters there is no scientific basis on which to form any calculable probability whatever. We simply do not know" (1936, p. 113). 
Davidson (1982-83; 1991; 2002) has modernized Keynes's argument, using the statistical concept of nonergodicity (Hamilton 1994, pp.45-47). Ergodicity is a feature of certain stochastic processes. An intuitive explanation of a nonergodic process might be useful to some readers. Suppose I have a single stochastic (random) process that is the law of motion for all economies in the world. All countries would be described by the same equation. However, different countries would have different data points at each point in time, because the random draws that determine the numerical value of each variable turn out differently in each country. For example, it might be that the equation governing GDP in each country has a different mean, drawn from a single world probability density function. But time series observations on the data for any one country would not converge on the overall mean governing all economies, but rather on the value of the individual country's mean. Panel data from all countries in the world would not arrive at the same sample moments as the moments of the process of any one given country.

All nonstationary processes (those whose moments, such as autocorrelations, are not the same at every date) are nonergodic in this sense. During the 1980s much empirical work was done on the stationarity of important economic time series variables. The debate has not been fully settled, but there is much evidence that most common variables are nonstationary.

The implication of nonergodicity is that future realizations of random variables, such as the profits of a particular firm, cannot be predicted based on prior empirical observations. Any given historical situation is unique, and statistical techniques cannot uncover how the unique situation will evolve from now on. Hence, firms cannot form any "rational expectations" of the $\mathrm{Q}_{i}$ 's, nor are the $\mathrm{Q}_{i}$ 's connected with any objective, observable data. They can be anything.

Nonergodicity applies to stochastic processes. Another type of process is deterministic, but also has interesting implications for the type of expectations that appear in investment demand equations. Consider how the complex behavior might affect the calculation of the $\mathrm{Q}_{\mathrm{i}}$ 's. One form of complex (or chaotic) behavior is sensitive dependence on the initial conditions. This means that we suppose hypothetically that the economy is in one of two certain states at date 1 . These two states (say, levels of GDP) can be arbitrarily close together. The state of the two economies at date (say) 100 may be very far apart. This is the famous butterfly example. (A butterfly flapping its wings could cause a powerful storm in another part of the world.)

If the world is chaotic (and many systems in the physical world indeed are), then it may be impossible to accurately determine the $\mathrm{Q}_{\mathrm{i}}$ 's in time 10 based on the data in time 1 . Any small error in measuring the initial state of the world could result in large prediction errors. Past observations may say that if the world is in state s in time 1, then it will be in state s' at date 10 . 
But these past observations will be of little use if we observe that the world is in a slightly different state (call it $\mathrm{s}^{*}$ ) in date 1 . For then, the date 10 observation can be $\mathrm{s}^{*}$, a situation far away from s' (Gandolfo 1997, pp. 503-505). Once again, the implication is that expectations of future profits, and hence NPVs and investment, follow no natural law that can be observationally detected.

$* * *$

Thus, in the view of Moore, the role of the interest rate is to act as a discount rate, or opportunity cost of funds, to be used in calculating the ex ante NPV of potential investment projects. This approach is consistent with much of the General Theory, including the notorious 17th chapter. But Keynes also argued at times that the true opportunity cost of investment funds was set, not on the market for bonds or other interest-bearing assets, but on the stock market.

Keynes argued as follows: "[The daily revaluations of the stock exchange, though they are primarily made to facilitate transfers of old investments between one individual and another, inevitably exert a decisive influence on the rate of current investment. For there is no sense in building up a new enterprise at a greater cost than that at which a similar existing enterprise can be purchased: whilst there is an inducement to spend on a new project what may seem an extravagant sum, if it can be floated off on the Stock Exchange at an immediate profit" (1936, p. 151).

The argument would run as follows. Suppose that a firm operating one textile mill is valued on the stock market at a total capitalization of 100 million dollars. Then, a second firm wishing to expand its output would be foolish to invest 200 million dollars in building a new mill. Hence, an important determinant of investment is the ratio, Q (no subscript), of the market capitalization of the relevant type of firm to the cost of purchasing new capital equipment on the market for goods. If the ratio is greater than one, a firm wishing to expand its capacity will prefer to build a new factory, purchase new software, etc., rather taking over an existing firm. If Q is less than one, the firm will take over a rival instead. Q can be defined as (Palley 2001).

\section{$\mathrm{P}_{\mathrm{E}} \mathrm{E} / \mathrm{KP}_{\mathrm{K}}$}


Where $\mathrm{P}_{\mathrm{E}}$ is the price of the firm's stock, $\mathrm{E}$ is the number of outstanding shares, $\mathrm{K}$ is the number of capital goods, and $\mathrm{P}_{\mathrm{K}}$ is the price of capital goods. (The credit market is simplified away.) If markets are rational, they will value the firm's equity at the expected discounted value of future profits, NPV+C. Moreover, K.P. $\mathrm{K}_{\mathrm{K}}$, the replacement value of the firm's capital goods, will be equal to $\mathrm{C}$, where $\mathrm{C}$ is the aggregate price of all ongoing investment projects. Putting these relationships together,

$\mathrm{Q}=\mathrm{P}_{\mathrm{E}} \mathrm{E} / \mathrm{KP}_{\mathrm{K}}=(\mathrm{NPV}+\mathrm{C}) / \mathrm{C}$

Q theory then says that firms should undertake investments for which $Q>1$. Introducing this condition leads to

$\mathrm{NPV}+\mathrm{C}>\mathrm{C}$

Or

$\mathrm{NPV}>0$.

This view of the determinants of investment does not leave out the role of interest rates. In fact, $Q$ will be determined in part by the ruling rate of interest. If an investor can earn a return of 10 percent on government bonds, then the value of $Q$ must allow for at least a 10-percent return on stocks. The rate of interest enters the expression for Q in the NPV term.

One advantage of Q theory over the Keynesian theories described above is that the latter did not peg investment to any observable variables. This raises the possibility of ad hoc explanations such as: the economy is in a recession, so it must be that the state of expectation was poor. The very uncertain basis for Keynesian expectations makes it difficult to test the theory or come up with determinate results (Eatwell and Milgate 1983, p. 13). On the other hand, Q is observable. We can test Q theory by observing the effect of Q on investment, and, hence, on output and employment. 
Next, this paper will present some criticisms of Keynes's theories, starting with Q theory, and then moving to problems with cost of capital-based theories in general. The progenitors of Q theory always recognized empirical problems. Specifically, the number that is relevant is "marginal" Q, or the Q of a new investment, not the Q of an entire business. Clearly, in deciding whether to build a new factory, a business will consider the likely profitability of that investment, not previous ones. So, observed stock market values are not the appropriate numerator of Q. It is difficult to find any empirically verifiable metric of marginal Q. This fact reduces the appeal of Q, as opposed to a theory that bases investment purely on the (unobservable) subjective expectations of businesses.

Efforts to empirically test Q theory using actual stock indexes have not been successful. It is interesting to notice that the ratio of takeover activity to investment tends to be at its highest when stock market valuations, and hence Q, are highest (Medlen 2003). This observation suggests that takeover activity is not a matter of bargain hunting when markets are undervalued, but of a general bullishness affecting both merging firms and other stock purchasers. Real investment does not always benefit from stock market bullishness. This suggests that merger activity and stock market valuation are part of the same (important) phenomenon, with real investment determined by other forces.

It is also important to recognize that Q relies upon strong assumptions about the motivation of managers and the rationality of stock market investors. A moment ago, it was assumed that both managers and firms have identical and correct expectations about future revenues. This rendered the $\mathrm{Q}>1$ and NPV $>0$ conditions identical. This sort of assumption is what has led some critics of the theory to argue that it conflates the interests and knowledge of managers with stockholders and assumes that the latter are completely rational (Crotty 1990; 1992). It is easy to drop the assumption of perfect foresight of the Q's by replacing them with (possibly irrational) expectations based on partial information. It then seems likely that the expected $\mathrm{Q}_{\mathrm{i}}$ 's of the managers of a firm will differ from those of the stock markets. Then the $\mathrm{Q}$ and NPV criteria will give diverging signals regarding the desirability of new investment. Firms may be interested in making investments whose Q is less than unity.

Another problem with Q is that managers may set goals that are independent of stock market valuations. For example, managers may maximize sales growth, with profitability 
considerations acting as a mere constraint (Palley 2001). They may have a different discount rate than financial markets. This observation is simply an example of a principal-agent problem, which arises because shareholders' and managers' interests are not identical (Crotty 1990, 1992; Palley 2001).

Keynes saw a role for the "animal spirits" of "entrepreneurs," not just those of stock market investors. He states that small businesses, before the predominance of public corporations, "embarked on business as a way of life, not really relying on a precise calculation of prospective profit" (1936, p. 150). Even now, Keynes believed, "Enterprise only pretends to itself be mainly actuated by the statements in its own prospectus, however candid and sincere. Only a little more than an expedition to the South Pole, is it based on an exact calculation of benefits to come" (p. 161).

There are thus two possible explanations of the rate of investment that depend on what Keynes dubbed "the state of expectation." First, the entrepreneurs invest when they are confident of the profitability of investment. Second, and alternatively, entrepreneurs make their choices with an eye on the stock market valuations of their firms. These market values are in turn determined by the state of expectation of the stockholders. The question then becomes whether entrepreneurs, when animal spirits move them, have the ability to initiate new investments. It will be argued below that large corporations, at least, have access to internal funds, which will enable them to make their own decisions, based upon their own estimates of the $Q_{i}$ 's in their own NPV calculations.

It must be emphasized that the Keynesian theory as portrayed above, even if fully accepted, is not as favorable as sometimes thought to the view that interest rates have an important influence on business investment. Keynes emphasized the importance of expectations of profits in determining the $\mathrm{Q}_{\mathrm{i}}$ 's above. These were largely conventional, with little basis in definite fact, and they could change very rapidly. This suggests the possibility that movements of the $\mathrm{Q}_{i}$ 's (expected revenues) are so wide that they swamp any reasonable changes in $\mathrm{r}$. In other words, shifts in what is called the marginal efficiency of capital curve [showing the interest rates at which the NPV of successive projects is equal to zero] are more important than movements along the curve.

In considering this possibility, Keynes says that interest rates "exercise[], at any rate, in normal circumstances, a great, though not a decisive, influence on the rate of investment. Only experience, however, can show how far management of the rate of interest is capable of 
continuously stimulating the appropriate level of investment" (Keynes 1936, p. 164). He then states the case more strongly: "It seems likely that the fluctuations in the market estimation of the marginal efficiency of different types of capital will be too great to be offset by any practicable changes in the rate of interest." In other words, the Fed may move interest rates in a range between 2 and 8 percent, but estimates of the profitability of investment may range between negative 20 percent and 20 percent. If the expected rate of return of an investment, because of a weak state of confidence, falls to negative 20 percent, the central bank will not be able to cause that investment to be made, even if it lowers interest rates to the bottom of its range. Expectations of rates of return and NPV's are likely to have a wide range, because of the fact emphasized above that they have no rational basis.

Another difficulty with the NPV and Q theories of investment is that they rest on an inverse relationship between the amount of investment or capital on the one hand, and the interest rate on the other (Rogers 1989, ch. 2; Eatwell and Milgate 1983; Garegnani 1983). One can see this if one watches the present value of all projects as the rate of discount rises. As the rate rises, fewer and fewer investment projects will meet the positive NPV condition. So, there will be less demand for investment funds. One can thus map the total demand for investment funds against the interest rate. Some authors reject this relationship for two reasons: 1) (the analytical reason) the inverse relationship does not have any foundation in logic, since the cost of capital represented by any given set of machines, factories, etc. is itself a function of the interest rate; and 2) (the pragmatic reason) the relationship in question guarantees the existence of a full-employment rate of interest. If 2 ) is true, and if the economist can posit some mechanism whereby the interest rate automatically falls in times of recession, he or she can argue that the private economy will spontaneously achieve full employment without government intervention (Garegnani 1983, p. 55). The first point is thought by some to be an implication of the outcome of the famous Cambridge Capital Controversy, which this paper will not cover in detail. Not all of the critics of neoclassical capital theory who were active in the controversy agree that it implies that NPV theories of the type used in some Keynesian macroeconomics are invalid or logically flawed (Robinson 1983).

Several additional problems arise in connection with all cost-based theories of business investment, such as Moore's and Q theory. Both of these theories are "price" theories, in that they make investment a function of the cost of external funds (either bond issues, bank loans, or equity issues). It is important to keep external funds in perspective. In 2003, capital expenditures 
by nonfarm, nonfinancial corporations amounted to $\$ 764.9$ billion. This figure stands against $\$ 797.7$ billion in U.S. internal funds, a rough measure of the retained earnings of corporations available for investment projects. So, corporations need not have borrowed any net funds to pay for capital expenditures (the majority of which went toward fixed investment, which includes new structures, software, and equipment). And indeed, they raised only $\$ 97.5$ billion via bond and equity issues, new short-term commercial paper, and other capital market instruments combined (Federal Reserve Board 2004, Z1 release, table F102).

Cross sectional data from Europe indicates a similar situation (Chatelain et al. 2003 and author's calculations). The mean ratio of cash flow to investment for Italian firms was 1.37, for French firms 2.70, for Spanish firms, 1.99, and for German firms, 1.57. These data accounted for firms employing at least 19 percent of the workforce in all four countries.

Many firms are not even on the market for borrowed funds. Only about 8 percent of the thousands of firms in the U.S. Compustat data set raise money through commercial paper programs. (Carpenter, Fazzari, and Petersen 1994, p. 83) An additional 12 percent of these firms raise money in the bond markets but not via commercial paper. Many firms do not have bond ratings and must raise any external funds through private placements.

There are many reasons why firms use mainly their profits to finance investment. One key fact is that there is often a wide spread between the bid and ask prices for finance (Eichner 1991). That is, firms must pay more for loans than they can earn in financial investments. One reason for this sort of spread is that high agency and transactions costs push the cost of capital to firms much higher than the return on risk-free assets. Agency costs include the costs of monitoring and enforcing debt contracts and setting aside funds to cover default risks. Agency costs would theoretically be highest for small firms whose financial situations are not tracked by bond-rating agencies, Wall Street firms, and the business press. Indeed, data show that the smallest industrial firms rely most on internal finance (Fazzari, Hubbard, and Petersen 1988, p. 147). On the other hand, in oligopolistic industries, leading firms generally possess sufficient pricing power to raise needed funds. So those firms who may most need external funds often cannot obtain them, and vice-versa.

John Kenneth Galbraith interestingly traces the use of internal funds to a need by corporations to reduce uncertainty: "Control of the supply of savings is strategic for industrial planning. Capital use is large. No form of market uncertainty is so serious as that involving the terms and conditions on which capital is obtained. Apart from the normal disadvantages of an 
uncertain price, there is the danger that, under some circumstances, supply will not be forthcoming at an acceptable price. This will be the precise moment when misfortune or miscalculation has made the need more urgent. And unlike the suppliers of raw materials or labor, the supplier of funds has traditionally been conceded some degree of power. The provision of credit carries with it to know, and even to suggest, how it is used. This dilutes the authority of the planning unit [corporation]. All of these dangers and difficulties are avoided if the firm has a secure source of capital from its own earnings" (1985 [1967], p. 36).

The more conventional argument, involving agency costs, has been fashionable for some time in neoclassical circles, but arguably has post-Keynesian roots. Kalecki argued for the "principle of increasing risk," which has a resemblance to some more modern theories (1968, chapters 8 and 9). In Kalecki's view, firms tended to try to limit their reliance on outside sources of finance. One reason is that even publicly traded companies were not "brotherhoods of shareholders." Insiders tend to have a grip on most companies, and the use of stock issues to raise money can potentially dilute their interest. Any use of borrowing can lead to a possibility of bankruptcy, which would lead to a loss of control to creditors. Short of bankruptcy, high interest costs can increase the possibility of capital losses in the event profits are not sufficient to pay financing costs. These sorts of risks to insiders (which Kalecki referred to as borrower's risk) increase as the extent of external finance increases.

All of this led Kalecki to posit that investment was a function of entrepreneurial capital or the gross savings (retained earnings) of firms. Not only could retained earnings be directly used to finance investment, but they also could be used as evidence of creditworthiness.

The emphasis on increasing risk was combined with more conventional theories in the work of several post-Keynesians, including Hyman P. Minksy (1975, 1986). Minsky's theory was known as a "two-price" theory, and the ratio of the two prices resembled Q in some respects. However, Minsky added some twists that made his theory both more realistic and more robust to critiques such as Kalecki's. 
FIGURE 2

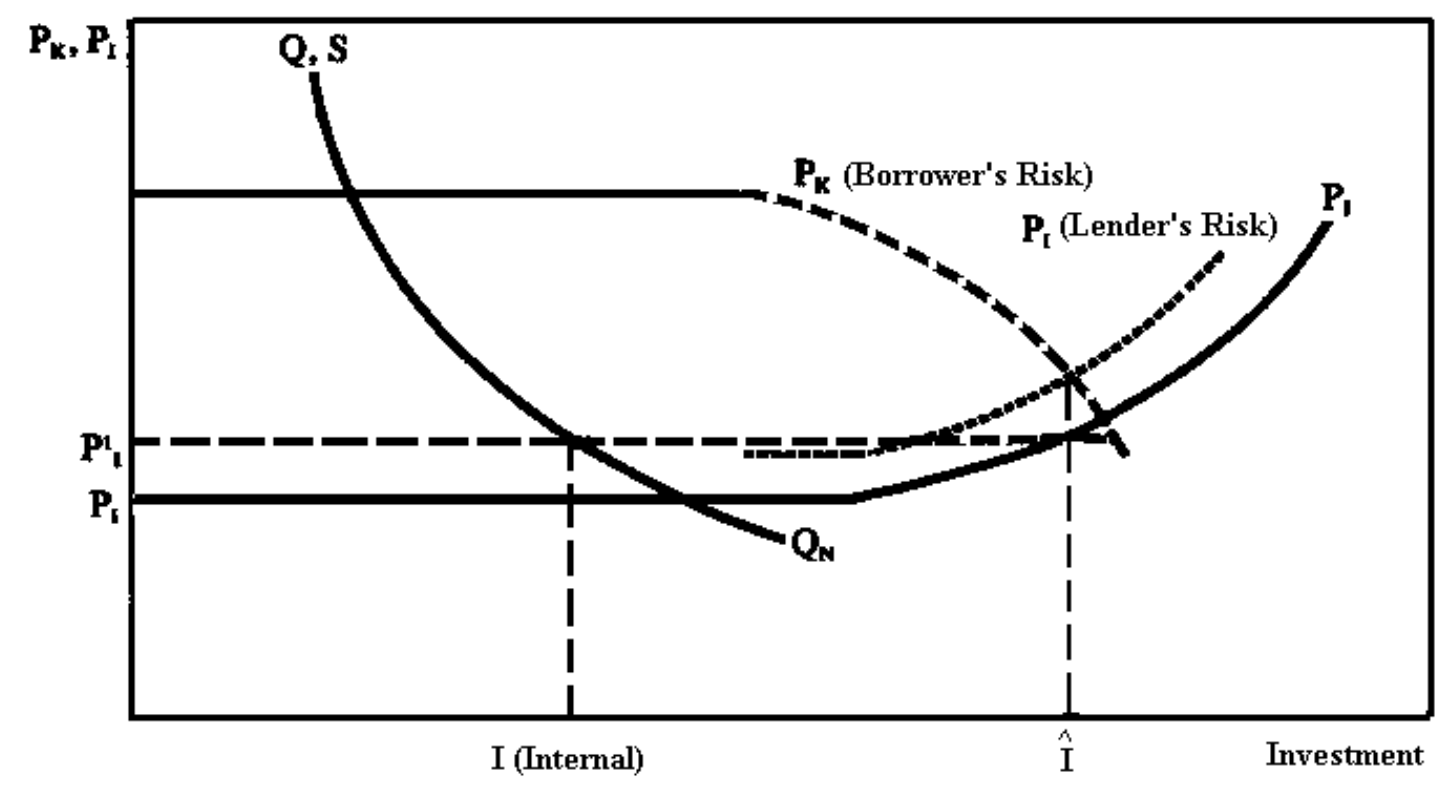

Source: Minsky (1986, p. 191)

The first price in Minsky's theory was the supply price of capital goods. The second was the demand price. Both of these prices were represented in the "two-price diagram" as schedules of prices for all potential levels of investment. As shown in figure 2, the supply price of capital rises with increasing investment $\left(\mathrm{P}_{\mathrm{I}}\right)$. There are two reasons for this. First, costs of production of investment goods rose with increased output, just as in any Marshallian supply curve. Second, lender's risk was added to the costs of capital ("P $\mathrm{P}_{\mathrm{I}}$ lender's risk" in the graph). This was reflected in "higher stated interest rates, in terms to maturity, and in covenants and codicils. Covenants and codicils might restrict dividends, limit further borrowings, and constraint the sale of assets; they might also require the maintenance of some minimum stated net worth." All of these restrictive terms reflect concern by the lender that it is incurring increasing risk as it extends greater and greater amounts of credit. The terms reflect conventional margins of safety, such as maximum debt-equity ratios. These margins can change over time, for example, when lenders become more complacent after a long period of prosperity.

The demand price for investment (" $\mathrm{P}_{\mathrm{K}}$ Borrower's risk") determined by different factors, also reflected the importance of margins of safety. As in Kalecki's argument, higher levels of investment increased risk not only to lenders but also to those who directly controlled the investing company. This increasing borrower's risk implies that the demand price for capital 
schedule slopes downward, which is also shown in the diagram. A third line $\left(\mathrm{Q}_{\mathrm{N}}\right)$ indicates the flow of internal funds. This schedule is a hyperbola because it represents constant nominal revenues, which are the product of the (price and quantity) variables on both axes. It is only the amount of funding to the right of that curve's intersection with the supply-price curve that must be financed externally.

The level of investment is given by the intersection of the $\mathrm{P}_{\mathrm{K}}$ (Borrower's risk) and $\mathrm{P}_{\mathrm{I}}$ (Lender's risk). This point is determined by many factors: the conventional margins of safety of firms and financiers, the uncertain expectations as to the profitability of a given venture, the availability of internal funds, and other factors. One could see it as a $\mathrm{Q}$ theory with an additional emphasis on conditions of finance, or a Kaleckian theory with an increased weight on the psychology of market participants.

The importance of so many nonprice factors would lead one to suspect that empirical studies would indicate a low elasticity of investment to interest rates. One recent study of user cost elasticities in the United States found, in its "preferred parsimonious specification" that none of its user-cost elasticity estimates differed by more than two standard deviations from .25. (Chirinko, Fazzari, and Meyer 1999, p. 69). The long-run user cost elasticities found in one recent study were -.663 in Germany, -.106 in France, -.111 in Italy, and -.259 in Spain (Chatelain et al. 2003). There are two further considerations. First, user cost has many components and is affected by depreciation and other variables. Hence, the elasticity of user cost with respect to the interest rate is often fairly small; even if user cost is an important determinant of investment, interest rate policy may not be a good way to reduce user cost. The second point is that the elasticities above change in the presence of a cash flow variable to -.521 , $-.027,-.204$, and -.278 , respectively. This leads one to expect that interest rate changes may exert their influence partly through their effect on cash flow, a statistically significant variable in its own right. Chirinko et al. note the same phenomenon and apply the term "income effect" in contrast to the substitution effect between inputs from standard economic theory.

Let us explore this idea further. The lack of a traditional "interest rate channel" does not imply that interest rates do not matter for firms. Davidson has emphasized the importance of cash flow commitments in an uncertain world (2002, p. 78). Agents use forward contracts, denominated in money terms, to help reduce the uncertainty they face about the terms of future transactions. Hence, the possession of adequate cash reserves and cash flows is essential in a capitalist economy. "In an entrepreneurial system where it is always possible that unforeseeable 
events may make it difficult to meet one's future contractual obligations, a primary consideration in the plans of all participants in the system is that before they put their plans into operation they need to possess sufficient liquidity to meet their existing and planned future contractual liabilities as well as to have ample liquidity to meet emergency future contractual agreements" (p. 74). Davidson emphasizes the importance of money in criticizing general equilibrium theory. In that sort of theory, all payments for the rest of time are settled in a single period, eliding the problem that Davidson sees as so crucial. "Logically consistent mainstream theory emasculates the importance of money, cash inflows, cash outflows and liquidity from any historical time setting. There are never any cash-flow problems in the model." On the other hand, "In the real world, payments and receipts are contractually generated in the form of money in a sequential time setting as buyers and sellers engage in spot and forward markets...Liquidity is a fundamental recurring problem whenever people organize most of their income receipt and payment activities on a forward money contractual basis. For real world enterprises and households, the balancing of their checkbook inflows and outflows to maintain liquidity is the most serious economic problem they face every day of their lives" (p. 78). The importance of money contracts is what makes money nonneutral in the long run (1991, p. 9).

One important forward contract denominated in money is the debt taken on by the firm to finance the purchase of some form of capital good. An increase in debt allows a firm to make more discretionary purchases. But each loan adds to a legacy of past debt, requiring cash interest payments. Minsky emphasizes the cash flow aspects of the acquisition of capital assets (1986, ch. 8). The role of interest payments in cash flow calculations can be shown with a simple equation (Eichner 1991, p. 472; notation slightly changed).

$\mathrm{E}=\mathrm{F}+\Delta \mathrm{D}-\mathrm{DS}$

where $\mathrm{E}$ is the amount of funds available to the firm to make discretionary expenditures such as investments, $\mathrm{F}$ is the amount of internal funds, or cash flow, $\Delta \mathrm{D}$ is the change in the firm's debt, or the amount it borrows during a given period, and DS is the firm's debt service costs on previously incurred debt. Now, additional loans affect $\mathrm{E}$ in two ways. First, they temporarily add to funds currently available, through an increase in the $\Delta \mathrm{D}$ term. Second, they permanently add to the DS term. If funds are borrowed in the form of perpetuities that pay a given amount of interest every period forever, then the change in $\mathrm{DS}$ for a given $\Delta \mathrm{D}$ is simply $\mathrm{r} . \Delta \mathrm{D}$, where $\mathrm{r}$ is 
the interest rate on the loan. While the funds newly raised help the firm make purchases in the period in which they are obtained, they add to the firm's debt service costs forever, which compromises future cash flow. Less cash flow is available for discretionary purchases in the long term.

This leads to an important possible avenue for the interest rate to affect investment, even when conventional channels of influence are not operative. Given that the DS term in the equation is proportional to the interest rate, any increase in rates translates into a reduction in available cash flow (Chirinko, Fazzari, and Meyer 1999). And, as we have argued, cash flow is perhaps a more important determinant of investment than cost-of-capital variables.

Minsky, like Davidson, puts a strong emphasis on the cash flow aspects of finance. He divided firms into hedge, speculative, and Ponzi units (1975; 1986). A hedge unit has adequate cash flow to pay both the interest and principle on its loans. A speculative unit cannot meet commitments to repay principal out of ongoing cash flows. Therefore, it must borrow money to repay the principal of its outstanding loans. Finally, a Ponzi unit must borrow money to pay both interest and principal. In terms of the equation above, for a Ponzi unit, F is less than DS, so that $\Delta \mathrm{D}$ is used to offset DS. When a large number of firms become Ponzi units, the economy reaches a state of what Minsky called "financial fragility." In particular, the economy would be vulnerable to increases in interest rates. In fact, note that any firm that is financing long-term projects with short-term borrowing is a Ponzi firm by Minsky's definition.

A closely related means of monetary transmission could be dubbed the cost-push channel (Barth and Ramey 2002; Taylor 2004, pp. 89-90; Hannsgen 2004). Interest rates, the argument goes, are a component of costs; when they rise, they have the same effect as any other increase in costs. The resulting inflationary effect has been used to explain the long-observed positive correlation between interest rates and prices or inflation. (See figure 1 for a variant on this finding.) Thomas Tooke, the first to note the correlation (later known as Gibson's paradox), stated the point in this way: "Suppose, then, that the reduced rate is general, and the loans of such length of time as to admit of being extensively acted upon by the different dealers of commodities... [Then] the diminished cost of production hence arising would, by the competition of the producers, inevitably cause a fall of prices of all the articles into the cost of which the interest of money entered as an ingredient" (1844, quoted in Garegnani 1983, p. 78).

Our concern is with effects on output, rather than prices. In a theory in which prices are determined by costs, interest rate hikes can lead not only to price increases, but also to changes 
in the distribution of income between those who earn interest and those who have few investments (Sraffa 1960; Pivetti 2001). They can also raise the relative prices of goods in which interest payments are an especially important "ingredient." Such changes in distribution and pricing could clearly, by affecting the demand for commodities, lead to changes in the composition and amount of output.

\section{$* * *$}

All of the possible channels of monetary policy transmission examined so far involve the business sector. But it is no secret that consumers have been borrowing at a furious rate; surely low interest rates can affect their spending. Net household borrowing climbed rapidly during the 1990s and early 2000s, reaching roughly 12 percent of GDP in 2002, led by a boom in home mortgage refinancings (Shaikh, Papadimitriou, Dos Santos, and Zezza 2003, p. 5). This development was clearly related to the downward trend in consumer rates that began in the early 1980s (ibid.). But for many less well-off consumers, interest rates are primarily driven by the markups charged by banks and other lending institutions to compensate for the risk of default, rather than by the cost of funds (Palley 2002, p. 22). It is hard to imagine that monetary policy alone could ever cause a repeat of the 10-percentage-point fall in mortgage rates that took place from 1982 to 2003. Moreover, borrowing is often driven by constraints, rather than its relative price. On the one hand, many consumers are limited by the amount banks are willing to provide them. On the other hand, these same consumers may be in such dire straits that they feel they have to take advantage of loans they can obtain at any rate. This leads to the observation that in 1998 , households with incomes under $\$ 50,000$ had a debt-income ratio of 2.98 , while those with incomes above that figure had a ratio of 1.40 (Palley 2002, p. 21). Households so deeply in debt as the former group may not be very responsive to slight changes in interest rates. As with corporate business, it may be those households who least need credit who are most able to obtain it.

\section{$* * *$}

Particularly in small open economies, the most important effect of interest rates may, naturally enough, involve cross-border transactions. Since the 1960s, the world's capital markets have 
been opened. As a result, changes in interest rates can cause shifts in the capital account. Now that foreigners can invest in domestic securities and currency, they may respond to an incremental increase in the domestic interest rate by first buying domestic currency and then converting it into domestic financial investments. Such purchases are thought to increase the value of the home currency, which of course can impact imports and exports.

In the exogenous-money world, inflows of foreign capital can cause domestic inflation, similar to any other increase in the money supply. But post-Keynesians have different ideas about the role of capital flows (Lavoie 2001; Godley and Lavoie 2004). Post-Keynesians have always downplayed the influence of increases in the money supply. If a firm has too much money, it generally purchases an interest-bearing asset, such as a government bond. The central bank is happy to sell the bond, because it wishes to keep the rate of interest on bonds constant, and a purchase by a private individual would otherwise have a tendency to lower the return. Hence, there is no "excess" money sloshing around causing trouble. One could substitute for the word bond in the last few sentences the words "certificate of deposit," "treasury bill," or "commercial paper."

Heterodox thinkers believe that a similar process occurs when capital flows into a country. Following a domestic interest rate rise, foreign investors purchase domestic securities from domestic nationals. These sellers then deposit their foreign funds in a bank, exchanging them for domestic currency or bank deposits. The bank then presumably sells the foreign exchange to the central bank in return for reserve deposits. But the process does not stop there. Unless the county's demand for currency has for some reason risen, the bank will want to exchange its new reserves for earning assets, such as government bonds. Once again, the central bank is happy to oblige by selling a bond; if it does not, the price of bonds will be bid up above target. Finally, the money supply is at the same demand-determined level. The central bank holds more foreign reserves; if it should attempt to sell them, the domestic currency would appreciate. However, there is nothing automatic or inevitable about such an attempt.

An example is the recent building up of huge stocks of foreign reserves by several East Asian central banks. Eventually, these reserves may be sold off in an abrupt manner, causing a crisis. But for now, no spontaneous adjustments of the exchange rate will take place. For some theorists holding views of this sort, the exchange rate is very similar to the interest rate or stock prices in Keynes's thought, in that all three are set largely by convention and mass psychology (Vernengo 2001). The situation of a country losing reserves is not identical to that of the country 
absorbing reserves, but most nations hold sufficient foreign reserves to "buy back" all their currency and central bank deposits (Obstfeld and Rogoff 1995, p. 78).

Nonetheless, capital flows often have an impact on exchange rates. The main neoclassical theory of the impact of interest rates on exchange rates, the so-called uncovered interest parity condition, finds little empirical support. But for relatively large countries, interest rate moves can be used roughly to set an appropriate exchange rate. As Wicksell put it, "A country which maintains sufficiently high its borrower's and lender's rates of interest need never fear that its notes will depreciate. In theory, indeed, it should much rather be possible for such a country to raise its currency to any height...irrespective of anything that is taking place abroad in the monetary sphere" (Wicksell, quoted in Vernengo 2001). Of course, this ability is very limited in a small open economy, where slight changes in interest rates can cause an overwhelming flood of capital in one direction or another. But domestic interest rates are forced into exact equality with foreign rates only when the liabilities of all countries are perfectly substitutable in the eyes of investors. The ongoing "home bias" in financial investment (a preference to invest in the domestic country's assets, all other things equal) is but one piece of evidence for a partial lack of substitutability.

Once exchange rates are affected, the impact on an economy can be large. Summarizing results of their own, which are in accord with those of other researchers, Godley, Izurieta, and Zezza (2004, p. 3) estimate that the effect on the balance of trade of a 10-percent devaluation would be about one percent of GDP, assuming GDP was held constant.

Interest rates can also have an important impact on the economy through their influence on asset prices. If interest rates are in the neighborhood of 2 percent, as they have been for some time in the United States, it makes sense for those with access to borrowed funds to purchase assets that offer a greater return. Clearly, one variant of this phenomenon is the purchase of stock "on margin," or with borrowed funds. Another option is to borrow funds to buy real estate that is expected to appreciate. A cycle can develop in which credit is used to buy assets, which rise in value. The increases in the value of the assets then can be leveraged for further asset purchases. If many investors are playing the same game, an asset bubble may develop. One might dub this form of monetary transmission the "speculation channel." 
So far, the effect of the interest rate has been examined from many angles. But this paper has neglected the issue of which interest rate is the relevant one. If short-term rates are the most important for investment, the Fed has great power. For while firms wishing to purchase capital goods do not borrow on the reserves market (which is closed to nondealers in the United States), all short-term rates fairly closely track open market rates (in the United States, the federal funds rate, or ffr). Rates at a maturity of up to about six months follow open-market rates because of the possibility of arbitrage.

It is important to realize that in an endogenous-money world, it is always the other interest rates that adjust to the ffr, rather than vice-versa. The federal funds rate in an endogenous money world (all real economies) is targeted by the central bank. So, an incipient change in the ffr is always nipped in the bud by the central bank, unless the bank wishes to change deliberately the ffr. So, if the ffr should start to rise above (fall below) the central bank's target, the Fed purchases (sells) securities, causing a return to target. This means that all short rates are forced to adjust to the open-market rate, as set by the central bank.

Figure 3 shows the relationship between various short term interest rates. This chart shows just how pervasive the arbitrage is in short-term credit markets. It is clear that to control the federal funds rate is to control the entire range of short term interest rates.

\section{FIGURE 3}

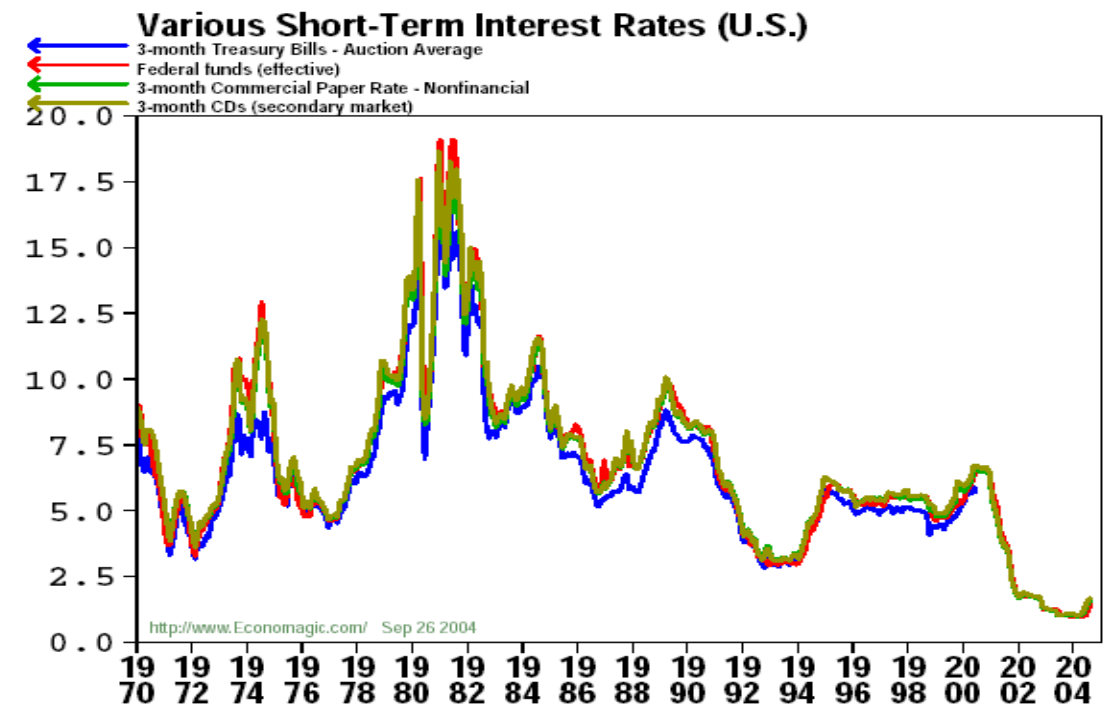


Short-term interest rates are probably not as important as long-term ones. Almost by definition, the relevant rate for investment decisions is the long-term one. Fixed investment pays off over a long term, and firms are probably reluctant to finance a long-term project with shortterm borrowing, simply because of the risk of interest rate increases. (Inventories and working capital are more closely related to short-term rates.) Keynes himself noted this point: "Where...(as in the United States, 1933-1934) open-market operations have been limited to the purchase of very short-dated securities, the effect [of open market operations] may... be mainly confined to the very short-term rate of interest and have but little reaction on the much more important long-term rates of interest" (1936, p. 197).

Clearly, long-term interest rates are subject to the same kind of arbitrage seen in the case of different short-term rates. If an investor expects the short-term rate to stay at two percent with 100 percent certainty, then he or she can with confidence invest in a long-term bond yielding three percent. But over the longer term, the fundamentals of bond value, including the shortterm rate, are likely to change. Therefore, in contrast to investors in short-run instruments such as commercial paper, bond investors must be wary of capital loss. There are many reasons why capital loss might occur, but Keynes emphasized capital loss due to a rise in yields, which move in the opposite direction of bond values. The intuition of such capital losses is as follows: 1) a bond promises to pay a certain amount of money at some future date(s); (2) if, at some point after the investor has purchased the bond, the interest rate rises, then the price of future money payments will fall and (3) hence, the value of the original bond falls.

Keynes used a formula to show how the prospects of a capital loss might affect the actual rate of return of a fixed-income investment such as a bond. The change in the return of the security (including capital loss), $R$, due to a change in the short-term interest rate $\left(R_{c}\right)$ would be $\mathrm{i}_{\mathrm{c}}\left(1-\mathrm{di}_{\mathrm{c}} / \mathrm{i}_{\mathrm{c}}{ }^{2}\right)$, where be $\mathrm{i}_{\mathrm{c}}$ is the interest rate, $\mathrm{di}_{\mathrm{c}}$ is a change in the rate, and is a short length of time (Taylor 2004, p. 140).

This formula leads Keynes to note: "If, however, the rate of interest is already as low as 2 percent, the running yield will only offset a rise in it of as little as 0.04 percent per annum. This, indeed, is perhaps the chief obstacle to a fall in the rate of interest to a very low level...[A] long-term rate of interest of (say) 2 percent leaves more to fear than to hope, and offers, at the same time, a running yield which is only sufficient to offset a very small measure of fear" (1936 p. 202). The point is that the interest payments earned on a bond can be very low compared to 
the loss an investor can incur in the event of a capital loss due to a rise in rates. Moreover, the effect of a capital loss is magnified when interest rates are already low.

Now, capital losses on bonds are, in Keynes's eyes, just as uncertain as capital losses in stocks. Like the values of stocks, as pointed out above, bond values are based on a very fragile set of expectations. These expectations are in normal times governed by convention. But since the convention has little firm basis in fact, it is subject to rapid changes in response to minor changes in "fundamentals." This leads Keynes to state that "It is evident...that the rate of interest is a highly psychological phenomenon" (p. 202) or alternatively that "the rate of interest is a highly conventional, rather than a highly psychological, phenomenon" (p. 203).

Keynes was especially concerned with the case in which the interest rate was stuck at a level above that which was consistent with full employment: "The long-term rate may be more recalcitrant (than the short-term one) when once it has fallen to a level which, on the basis of past experience and present expectations of future monetary policy, is considered 'unsafe' by representative opinion" (p. 203). A given rate of interest may be particularly recalcitrant if it is thought to be "natural" or based on fundamentals, rather than convention (p. 204). However, it is possible for the central bank to change the psychology of the markets: "precisely because it is not rooted in secure knowledge, it will not be always unduly resistant to a modest measure of persistence and consistency of purpose by the monetary authority" (p. 204).

The fear-of-capital-loss theory of interest rate rigidity has some drawbacks. It rests on the notion that an expected "safe" rate of interest exists in the minds of investors, and that fears of capital loss set in once yields fall to that rate. But neo-Ricardian Keynesians such as Garegnani (1983) find this story unsatisfactory: "The position of the speculative demand for money schedule, and hence the rate of interest, thus comes to depend on expectations about the future course of the latter. However, in the absence of their ulterior explanation, these expectations introduce a serious element of indeterminacy into the theory" (p. 53). This is the same objection some economists raise against the animal spirits theory of investment determination: whatever data are observed, they can be justified ad hoc as the result of some vaguely specified psychological factors. More to the point, the "fear of capital losses" theory of long-term interest rates depends upon the existence of a "safe interest rate" below which concerns over capital losses predominate. To argue that this rate stays at a certain level for a prolonged period of time (long enough to cause a recession) one must assert that the "safe interest rate" remains stable even in the face of continuing data showing that capital losses are not in fact occurring. It seems more likely that the perceived safe rate would eventually fall in 
line with the actual rate (Garegnani 1983, p. 53). Then, no obstacle would exist to the achievement of any rate of interest; on the other hand, some other theory of the long-term rate would have to be found to replace Keynes's.

$* * *$

This paper shows that a plethora of explanations exist of the monetary transmission mechanism. In fact, several important theories have been left out. As the empirical results presented early in the paper show, interest rates do indeed have some impact on output. But empirics and theory alike caution us not to assume that monetary policy is all-powerful. It is possible that, given the uncertainty of the effects described here, the best use of monetary policy may be as a stabilizing tool, rather than as a gas pedal to maneuver the economy away from recession and excessive inflation. Then, the interest rate could be kept at a low level, as it was with some success in the United States immediately after World War II. If a gun is extremely imprecise and erratic, it may be best not to fire it at all. Rapid changes in interest rates may or may not affect fixed investment in the direction desired by policymakers. But it is known that the speculative channel does the most mischief when rates vary dramatically over time.

\section{REFERENCES}

Arestis, Philip, and Malcolm Sawyer. 2003. "The Nature and Role of Monetary Policy When Money is Endogenous." Working Paper No. 374. Annandale-on-Hudson, N.Y.: The Levy Economics Institute.

Barth, III, M. J., and V. A. Ramey. 2002. "The Cost Channel of Monetary Transmission.” NBER Macroeconomics AnnualVol. 16, 199-240.

Bernanke, Ben S., and Alan Blinder. 1992. "The Federal Funds Rate and the Channels of Monetary Transmission." American Economic Review, 82, 901-921.

Bernanke, Ben S., and Ilian Mihov. 1998. "Measuring Monetary Policy." Quarterly Journal of Economics, 113, 869-902. 
Carpenter, Robert E., Steven M. Fazzari, and Bruce C. Petersen. 1994. "Inventory Investment, Internal-Finance Fluctuations, and The Business Cycle." Brookings Papers on Economic Activity, 75-122.

Chatelain, J. B., A. Generale, I. Hernando, P. Vermeulen, and U. von Kalckreuth. 2003. "Firm Investment and Monetary Policy Transmission In The Euro Area." In Monetary Policy Transmission in the Euro Area, edited by I. Angeloni, A. Kashyap, and B. Mojon. Cambridge, U.K.: Cambridge University Press. 133-161.

Chirinko, Robert S., Steven M. Fazzari, and Andrew P. Meyer. 1999. "How Responsive Is Business Capital Formation To Its User Cost? An Exploration With Micro Data." Journal of Public Economics, 74, 53-80.

Christiano, Lawrence J., Martin Eichenbaum, and Charles Evans. 1999. "Monetary Policy Shocks: What Have We Learned and To What End." In Handbook of Macroeconomics, Vol. 1A. Oxford: Elsevier Science. 65-148.

Crotty, James R. 1992. "Neoclassical and Keynesian Approaches To The Theory of Investment." Journal of Post Keynesian Economics, 14, 483-495.

Crotty, James R. 1990. "Owner-Manager Conflict and Financial Theories of Investment Instability: A Critical Assessment of Keynes, Tobin, and Minsky." Journal of Post Keynesian Economics, 12, 519-536.

Davidson, Paul. 2002. Financial Markets, Money and the Real World. Cheltenham, U.K.: Edward Elgar.

Davidson, Paul. 1991. "Is Probability Theory Relevant For Uncertainty? A Post Keynesian Perspective." Journal of Economic Perspectives, 5, 129-143.

Davidson, Paul. 1982-83. "Rational Expectations: A Fallacious Foundation For Studying Crucial Decision-Making Processes." Journal of Post Keynesian Economics, 5, 182198.

Davidson, Paul. 1978. Money and the Real World. London: Macmillan.

Eatwell, J., and M. Milgate. 1983. "Introduction." In Keynes's Economics and the Theory of Value and Distribution, edited by J. Eatwell and M. Milgate. Oxford: Oxford University Press.

Eichner, Alfred S. 1991. The Macrodynamics of Advanced Market Economies. Armonk, N.Y.: M. E. Sharpe.

Fazzari, Steven M., R. Glenn Hubbard, and Bruce C. Petersen. 1988. "Financing Constraints and Corporate Investment." Brookings Papers on Economic Activity, 141-195.

Federal Reserve Board of Governors. 2004. Flow of Funds of the United States. 
Galbraith, John Kenneth. (1985 [1967]). The New Industrial State. Fourth Edition, N.Y.: New American Library.

Gandolfo, Giancarlo. 1997. Economic Dynamics. Study Edition, Berlin: Springer.

Garegnani, P. 1983. "Notes On Consumption, Investment and Effective Demand." In Keynes's Economics and the Theory of Value and Distribution, edited by John Eatwell and Murray Milgate. Oxford: Oxford University Press. 21-69.

Godley, Wynne, Alex Izurieta, and Gennaro Zezza. 2004. "Prospects and Policies for the U.S. Economy: Why Net Exports Must Now Be the Motor for U.S. Growth." Strategic Analysis. Annandale-on-Hudson, N.Y.: The Levy Economics Institute and Cambridge Endowment for Research in Finance.

Godley, Wynne, and Marc Lavoie. 2004. "Simple Open Economy Macro With Comprehensive Accounting - A Radical Alternative To The Mundell Fleming Model.” Working Paper No. 15. Cambridge, U.K.: Cambridge Endowment for Research in Finance.

Hamilton, James D. 1994. Time Series Analysis. Princeton, N.J.: Princeton University Press.

Hannsgen, Greg. 2004. "Gibson's Paradox, Monetary Policy, and the Emergence of Cycles." Working Paper No. 411. Annandale-on-Hudson, N.Y.: The Levy Economics Institute.

Kalecki, Michal. 1968. Theory of Economic Dynamics: An Essay on Cyclical and Long-Run Changes in Capitalist Economy. New York: Modern Reader Paperbacks.

Keynes, John Maynard. 1936. The General Theory of Employment, Interest and Money. New York: Harcourt, Brace and Co.

Lavoie, Marc. 2001. "The Reflux Mechanism and The Open Economy." In Credit, Interest Rates, and the Open Economy edited by Louis-Philippe Rochon and Matias Vernengo, Cheltenham, U.K.: Edward Elgar, 215-242.

Leeper, Eric M., Christopher A. Sims, and Tao Zha. 1996. "What Does Monetary Policy Do?" Brookings Papers on Economic Activity: 1-79.

Medlen, Craig. 2003. “The Trouble With Q.” Journal of Post Keynesian Economics, 25, 69398.

Minsky, Hyman P. 1986. Stabilizing an Unstable Economy. New Haven, Conn.: Yale University Press.

Minsky, Hyman P. 1975. John Maynard Keynes. New York: Columbia University Press.

Mojon, B., and G. Peersman. 2003. "A VAR Description of The Effects of Monetary Policy In The Individual Countries of The Euro Area." In Monetary Policy Transmission in the Euro Area edited by I. Angeloni, A. Kashyap, and B. Mojon. Cambridge, U.K.: Cambridge University Press. 56-74. 
Moore, Basil. 1988. Horizontalists and Verticalists: The Macroeconomics of Credit Money. Cambridge, U.K.: Cambridge University Press.

Obstfeld, Maurice, and Kenneth Rogoff. 1995. "The Mirage of Fixed Exchange Rates.” Journal of Economic Perspectives, 9, 73-96.

Palley, Thomas I. 2002. "Economic Contradictions Coming Home To Roost? Does The U.S. Economy Face A Long-Term Aggregate Demand Generation Problem?" Journal of Post Keynesian Economics, 25, 9-32.

Palley, Thomas I. 2001. "The Stock Market and Investment: Another Look At The MicroFoundations of Q Theory." Cambridge Journal of Economics, 25, 657-667.

Pivetti, Massimo. 2001. "Money Endogeneity and Monetary Non-Neutrality: A Sraffian Perspective." In Credit, Interest Rates and the Open Economy, edited by Louis-Philippe Rochon and Matias Vernengo. Cheltenham, U.K.: Edward Elgar, 104-119.

Robinson, Joan. 1983. “Garegnani On Effective Demand.” In Keynes's Economics and the Theory of Value and Distribution, edited by John Eatwell and Murray Milgate. Oxford: Oxford University Press, 70-71.

Rogers, Colin. 1989. Money, Interest and Capital: A Study in the Foundations of Monetary Theory. Cambridge, U.K.: Cambridge University Press.

Shaikh, Anwar M., Dimitri B. Papadimitriou, Claudio H. Dos Santos, and Gennaro Zezza. 2003. "Deficits, Debts, and Growth: A Reprieve But Not a Pardon." Strategic Analysis. Annandale-on-Hudson, N.Y.: The Levy Economics Institute.

Sraffa, Piero. 1960. Production of Commodities by Means of Commodities. Cambridge, U.K.: Cambridge University Press.

Taylor, Lance. 2004. Reconstructing Macroeconomics: Structuralist Proposals and Critiques of the Mainstream. Cambridge, Mass.: Harvard University Press.

Vernengo, Matias. 2001. "Foreign Exchange, Interest and Prices: The Conventional Exchange Rate." In Credit, Interest Rates and the Open Economy, edited by Louis-Philippe Rochon and Matias Vernengo. Cheltenham, U.K.: Edward Elgar, 256-70.

\footnotetext{
${ }^{1}$ For a justification of the use of the federal funds rate as a monetary policy variable, see Bernanke and Blinder (1992). For general explications of this type of monetary VAR and further results, see Christiano, Eichenbaum, and Evans (1999), Leeper, Sims, and Zha (1996), and Bernanke and Mihov (1998).
} 